\title{
KESELARASAN TEKNOLOGI DENGAN SUMBER DAYA MANUSIA
}

Dalam menghadapi transformasi digital seperti ini, sumber daya manusia yang berada di suatu perusahaan mempunyai peran sangat penting sebagai partner/rekan strategi untuk mendukung seluruh perencanaan dan tujuan perusahaan sebagai agen perubahan untuk membangun budaya kerja guna menyambut transformasi digital ini. Sebelum membahas lebih lanjut, transformasi digital ialah suatu perubahan pada penerapan teknologi digital dengan cara merevolusi bisnis dengan berbagai macam bidang teknologi yang baru di dalam aspek kehidupan masyarakat yang baru pula, seperti pembelajaran mesin, data besar, dan internet. Pada transformasi digital ini yang ingin membantu aspek kehidupan baru pada masyarakat tentunya pasti memiliki beberapa tantangan entah pada sektor bisnis kecil, menengah, ataupun pada perusahaan besar. Tantangan yang dimaksud bisa semacam, kultur antar budaya, kurangnya support dari pimpinan perusahaan/organisasi, dan kurangnya memahami customer. Bukan namanya tantangan jika tidak luput dari risiko yang dihadapi oleh masyarakat pada transformasi digital ini, mungkin bisa saja kurangnya sponsor terhadap pelaksanaan transformasi digital tersebut, harus dapat menciptakan lingkungan yang berbeda daripada biasanya, para pemimpin dapat mengubah mindset pada diri mereka sendiri, dll.

Dan secara umum pada sumber saya manusia, produktifitas kerja karyawan berbanding lurus dengan tingginya daya saing perusahaan/organisasi secara keseluruhan dalam menghadapi persaingan bisnis serta transformasi digital yang diterapkan. Keterlibatan karyawan ini terhadap perusahaan sangat dipengaruhi oleh beberapa faktor, diantaranya perilaku pimpinan, kompensasi karyawan, dan kebijakan dari karyawan itu sendiri. Maka, perlu dipahami bahwa hanya perusahaan/organisasi yang bersifat adaptif saja yang dapat bertahan di era globalisasi seperti ini yang ditambah dengan kondisi pandemi saat ini. Untuk itu dilakukan lah perubahan metode/cara, dengan meninggalkan metode lama yang begitu masif dengan menerapkan metode baru yang lebih efisien. Metode yang dimaksud terutama oleh beberapa perusahaan/organisasi ialah metode transformasi bisnis dan transformasi sumber daya manusia. Transformasi ini akan berjalan dengan baik bila perusahaan memiliki budaya organisasi yang kuat. Budaya perusahaan menjadi sangat penting karena berfungsi sebagai perekat yang kuat antar anggota perusahaan sekaligus sebagai penyatuan gerak dan langkah seluruh elemen dalam perusahaan. 
Hubungan keselarasan menunjukkan tidak hanya hubungan antara budaya organisasi dan anggota organisasi, tetapi juga hubungan antara budaya organisasi dan proporsi nilai organisasi dengan pemangku kepentingan eksternal terkait kepentingan atau konflik prioritas dalam proses bisnis untuk mewujudkan pemahaman tentang organisasi yang dibutuhkan. Saat ini dan ke depan perlu ada sistem seleksi pegawai yang tepat yang kemudian dikembangkan sesuai dengan kebutuhan lapangan kerja dan tuntutan organisasi. Pengembangan biasanya dilakukan melalui kegiatan pelatihan dan pemahaman budaya perusahaan untuk meningkatkan pengetahuan dan keterampilan karyawan, termasuk pemahaman secara menyeluruh tentang lingkungan organisasi. Kegiatan pelatihan selalu difokuskan pada keterampilan yang dibutuhkan untuk melaksanakan pekerjaan saat ini, sedangkan pengembangan karyawan dan manajemen merupakan latihan jangka panjang untuk memudahkan pemecahan masalah yang timbul dalam organisasi.

\section{Rizki Akbar, 130118061}


Reference

Ahmad Zafrullah Tayibnapis "Indonesia's Efforts to Achieve Globally Competitive Human Resources "International Journal of Humanities and Social Science Invention(IJHSSI), vol. 07, no. 8, 2018, pp. 01-06 